\title{
Public Debt and Economic Growth Nexus in Malaysia: An ARDL Approach
}

\author{
Foo Tzen YOONG ${ }^{1}$, Abdul Rahman Abdul LATIP², Nur Azura SANUSI ${ }^{3}$, Suhal KUSAIRI ${ }^{4}$
}

Received: August 01, 2020 Revised: September 20, 2020 Accepted: October 05, 2020

\begin{abstract}
The aim of this study is to find out the time-series nexus of public debt and economic growth in Malaysia. For an upper-middle income country, Malaysia had experienced over 50\% ratio of debt to GDP since 2009 until now. The question arises is whether this trend is healthy to the economy. With a focus into the debt-to-GDP ratio from 1970-2015, this study investigates the short-run and long-run relationship between public debt and economic growth in Malaysia. This study used secondary data by collecting time-series data (1970-2015) from the World Bank Data and Bank Negara Malaysia. Autoregressive Distributed Lag (ARDL) model is applied in this study to examine the relationship between debt and economic growth. Based on ARDL framework, it shows that there is a long-run effect between the debt and economic growth in Malaysia. While the significance value of Error Correction Term shows that there is a long-run adjustment in the short run. Generally, this study found government expenditures, in the long run, strongly influence the GDP per capita. Through the findings, the government expenditures could increase the GDP per capita. The study also reveals that any increment of the debt ratio will result in reduction of the GDP per capita.
\end{abstract}

Keywords: ARDL Approach, Debt Ratio, Economic Growth, Government Expenditure, GDP Per Capita

JEL Classification Code: C32, H50, H63, O47

\section{Introduction}

This section will examine the trend of debt ratio in Malaysia from 1970 to 2016. The trend will be further broken into several parts to study the special incidence or special events that could spark the changes in the debt-to-GDP ratio in Malaysia. The outline of this section is, first, a discussion of the general trend, and then we will move on to the pre-peak

${ }^{1}$ First Author. Faculty of Business, Economic and Social Development, Universiti Malaysia Terengganu, Malaysia.Email: tzyoong@gmail.com ${ }^{2}$ Corresponding Author. Lecturer, Faculty of Business, Economic and Social Development, Universiti Malaysia Terengganu, Malaysia [Postal Address: 21030 Kuala Nerus, Terengganu, Malaysia] Email: rahmanlatip@umt.edu.my

${ }^{3}$ Professor, Faculty of Business, Economic and Social Development, Universiti Malaysia Terengganu, Malaysia

${ }^{4}$ Associate Professor, Faculty of Business, Economic and Social Development, Universiti Malaysia Terengganu, Malaysia

(c) Copyright: The Author(s)

This is an Open Access article distributed under the terms of the Creative Commons Attribution Non-Commercial License (https://creativecommons.org/licenses/by-nc/4.0/) which permits unrestricted non-commercial use, distribution, and reproduction in any medium, provided the original work is properly cited. of debt ratio, then to the peak or climax in history and the failing of debt ratio. The financial crisis in 1997 and the subprime financial crisis also will be highlighted in the study.

In the beginning of 1970 , the debt ratio was $40.8 \%$ of the GDP in Malaysia and we could see that there is an increase for two consecutive years, which crosses the mark of $50 \%$. However, there is a slight decrease for the next two years, but it increased to 51\%. During the next five years (1975-1980), the debt ratio has been in the range of $44 \%-48 \%$. There are no significant changes in this time frame. Furthermore, from 1981 onwards, the debt ratio has been going up by breaking the record since 1970 . It has increase from $54 \%$ to $66.9 \%$, then until $73.4 \%$ before it fell slightly in 1984

1985 onwards, the debt ratio in Malaysia is remarkably high, which it exceeded $100 \%$ for two years in a row. After 1987, the debt ratio fell for the next 10 years and it reached $31.9 \%$, which is the lowest ratio ever recorded. The debt ratio has undergone a huge increase and then a downward trend in these 17 years.

The debt ratio fluctuates around 40\% from 1998 until 2008. In 2009, the debt ratio increased drastically from $39.8 \%$ to $50.8 \%$ and it fluctuated around $50 \%$. For the past five years, the highest debt ratio recorded was $54.5 \%$ in 2015 . 




Figure 1: Debt-to-GDP ratio trend in Malaysia 1970-2017

Overall, we could see that the debt ratio follows an increasing trend during the 1970s until the mid-1980s, then a downward trend from the mid-1980s until the end of 1990s. During the 1990s, the debt ratio has been stable at $40 \%$ before exceeding the $50 \%$ since 2009 until now.

\section{Literature Review}

Tan and Chin (2017) found the rising trend of debt level in Malaysia has brought up concerns among academics and policymakers about whether Malaysia would face a similar economic crisis like Greece. The long-run relationships of the variables were determined by estimating an equation using Johansen and Juselius Cointegration starting from 1980 until 2012. This study also uses Granger causality test to determine the relationship between public debt and economic growth. The results show that, in the long run, the debt ratio positively affects the economic growth. It also shows economic growth is significantly causing public debt in Malaysia.

Furthermore, another study by Zakaria and Nabi (2015) examined the existence of a causal relationship among economic growth, export and public debt in Malaysia using the VECM framework and the Granger Causality test between the period from 1970 to 2013 . The results found the presence of a long-run bi-directional relationship between public debt and exports in Malaysia. While the short-run causal relationship between public debt and GDP was not supported. However, it is shown that there is evidence in supporting the presence of uni-directional short-run causal relationship from exports to public debt in Malaysia.

According to the basic theory, fiscal deficit can be defined as the difference between the public expenditure and the public revenue for a period of one year. This is known as fiscal policy that is often used by the policymakers or public sectors to influence the country's economy. It is where the government will adjust the spending or the tax rate or both together in directing a country's economic goals. When governments announce the budget, they will either go for budget surplus (public revenue larger than public expenditure) or budget deficit (public expenditure larger than public revenue). The problem for budget deficit is that the government does not have enough fund for public services. Therefore, public sectors must obtain fund either internally or externally; it could be borrowing money from other parties, which also can be known as debt.

Similarly, in Blake (2015) paper, the physical and human capital of a country, the technological level, and the labor force are view as the main key drivers of economic growth. In another study, physical capital, government expenditure, and labor force were among the variables that exert a positive effect on Pakistan's economic growth (Tariq et al., 2020). But, the ability of a country's growth is highly dependent on the level of debt that the country carries. Debt by the government could ease growth through higher public investment and the public spending. However, countries must repay the debt that has been acquire beforehand that will boost the economic growth. Thus, for a country to repay the existing debt, the performance of the country should be higher than what the country has borrowed. Increased borrowing in the economy will crowd out private sector investment. According to Reinhart and Rogoff (2010), the excess of 90 percent ratio of public debt to GDP has a negative impact on economic growth.

In addition, the traditional Keynesian theory states that public investment (as part of GDP) should promote 
economic growth. Thus, in the short run, the expansion of government investment would promote economic growth by providing more infrastructure. However, recent studies show that an excess investment by the government could bring a negative effect to the nation's economic. This could be due to the excess government investment crowding in and the monopoly of government activities that causes the allocation of resources not fully utilized. Besides that, excessive government investment causes the demand to increase and the public debt will snowball and grow larger.

Alfredo et al. (2001) addresses both the Keynesian and Ricardian approaches on public debt as these classical and modern economic views are contradicting each other. The view on public debt from the Keynesian view is that the occurrence of public debt will leave an enormous impact on the economic performance, while the Ricardian view is that public debt leaves no effect to the macroeconomic performance. Keynesians view that public deficit will crow out private investment by taking away the savings from the private sector. Thus, this will cause the growth in the long term to be hampered because there is no savings from the people and then the demand for output will decrease. Their disposable income is lower. However, the Ricardian view is that deficit does not matter. Ricardians view that debtfinanced deficit is a delayed taxation. When running a deficit now, government will have to borrow; this implies that the government is spending the future income. This represent the future taxes on the children. Increased taxes in the future do not affect the macroeconomic performance of the economy.

On the other hand, Soludo (2003) finds that countries borrow for two main reasons, which is for macroeconomics reasons and for financing balance of payment deficit. For macroeconomics reasons, government borrow so that the investment could be increased and bring higher consumption in the nation. This moves by the government is by increasing the infrastructure in the country. The second reason is to lower the nominal interest rate aboard and solve the budget constraints. Both reasons implied that debt could boost the economic growth. Soludo argues that, when the debt threshold exceeds a certain percentage, the debt burden will increase and crowd out the investment and growth. This is happening in most of the advanced economy countries today. In his paper, he stated that Jordan has been borrowing a generous sum to put itself on a quicker route to development through investment and faster growth. But the indebtedness of Jordan and excess debt burden has gone beyond the limit that could help the economy to grow, it now put them into a worse place.

Matiti's (2013) study in Kenya analyzes the correlation between public debt and economic growth by combining external and domestic debt as the proxy. By using descriptive research and regression analysis, the results stated negative impacts of increasing in public debt to the economic growth.
However, he found the domestic debt is at risk and reduction of it should be formulated and implemented. Matiti's paper shows negative relation between public debt and economic growth and this finding suits the view of Keynesian economic theory. Study by Égert (2015) also indicates negative linear relationship among public debt and economic growth, but the threshold is roughly around or less than 20 percent. Égert (2015) also argues that the debt threshold observed by Reinhart and Rogoff (2010) for the US economy was not accurate because it was influenced by one single outlier. This is way lower than what Reinhart and Rogoff suggested. Similar to Matiti (2013) and Égert (2015), a study by Zouhaier and Fatma (2014) shows a negative effect of external debt on economic growth. This study was using the panel data model to examine the debt effect among 19 developing countries between the 1990 and 2011. Differing from Matiti (2013) and Zouhaier and Fatma (2014), Fekadu (2014) found that the flow of external debt in the short run has positively affect economic growth, but has a negative impact in the long run. This study concludes that low savings and lack of foreign exchange have cause the federal fiscal budget to widen and accumulated massive debt. It has made it more difficult for Ethiopia to manage and serve their huge debt. The high public debt will lead to high inflation, low savings, and denting the sovereignty of the country.

Conversely, Al-Zeaud (2014), in his empirical assessment of Jordan, described that the public debt triggers a strong and positive effect on the economic growth using the per-capita income approach, while the growth of the population has a strong and negative impact on the economic performance. The higher public debt could foster the economic growth in Jordan, while the population growth could possibly affect the economic performance negatively due to the increase in population, which has offset the increase in economic growth. Kumar and Paramanik (2020) revealed that financial development has a positively impact economic growth in the long run.

Aleksandar et al. (2014) conclude in their paper that high public debt does not affect economic development and it must not be the tool to strengthen economic growth. The use of debt as a source of investment and financing deficit will be borne by future generation. The impact such as slowing growth of the economy will be in a few years' time. As per Aleksandar, Ricardian's empirical result shows that the government budget deficit will not affect the output due to crowding out effect.

Carmen et al. (2016) investigated the relation between public debt and economic growth in 115 economies. Countries with a lower public debt have higher economic growth, while countries with higher public debt have lower progress on growth of their economy. This shows that debt will increase economic growth, while excessive debt will hinder the growth of the economy. 
Lee et al. (2015) examine the correlation between GDP per capita and public debt for the period between 1991 and 2013. The study shows that budget deficit and government consumption have negative effects on economic growth, except for budget expenditure. This paper looks at the direct effect of variables on economic growth and it did not examine the threshold level for debt in Malaysia. On the contrary, a study by Olilingo and Putra (2020) found government expenditure has a positive correlation with economic growth.

Most of the literature reviewed has shown that in the long-run, public debt will have a negative impact on economic growth, such as Combes et al. (2017), Schularick (2012), Égert (2015), and Carmen et al. (2016). Some papers didn't agree with Reinhart and Rogoff (2010) about the 90\% threshold, Combes et al. (2017) proved that it is around 87\% for 56 countries, while Mencinger et al. (2014) found that it is around $80 \%$ to $94 \%$. Da Veiga et al. (2019) found the variables related to public debt do not present any significant relationship with growth of economic.

Based on the literature reviewed, many studies prove a non-linear relationship between debt and performance of the economy. Further test will be carried out in this study to identify if there is any non-linear relationship between debt and economic growth in Malaysia. This paper will provide an empirical test on Malaysia since the latest empirical test was carried out in 2013. The model used in that paper was different. Different approach was used in these papers to examine the debt influence on economic growth. To fulfill the objectives of this study, the effect of debt on economic performance will be examine further in the next chapters.

\section{Research Methods and Materials}

\subsection{Sources of Data}

The time-series data from 1970 to 2015 for these variables are collected from World Bank Data and Bank Negara Malaysia. This kind of data is classified as secondary data or past data. The growth of GDP per capita is in the form of annual percentage, as are debt ratio and government expenditure. Household expenditure is in current RM. All these variables are processed using natural logarithm.

The variables can be defined as quantity, which could vary or capable of varying in value. There are two types of variables - independent variables and dependent variable. The focus of this study is the relationship between the independent variables and dependent variable. Growth of GDP per capita is the dependent variable, while the government expenditure, debt-to-GDP ratio, and household expenditure are the independent variables.
The measurement of LDEBT is the portion of government debt to the country's GDP. Debt of a country can be group into external debt and internal debt. The debt ratio is often used by government as the ability to repay its debt. Government final expenditure is the ratio of the government expenditure to GDP. Government expenditure can be defined as purchasing of goods and services such as investment, public consumption, and transfer. Household expenditure is the ratio of household's final consumption expenditure by residents for their daily needs such as food, clothing, transports, medicals and other needs. Real growth of GDP per capita is measured by the difference of percentage GDP per capita from the current year to the previous year. GDP per capita is calculated from GDP (the measure of total output in a country over one year) divided by the total population in that nation.

\subsection{Methods of Estimation}

\subsubsection{Augmented Dickey-Fuller (ADF) Test}

Dickey-Fuller is a test named in 1979 after two statisticians, David Dickey and Wayne Fuller. It tests the presence of unit root in an autoregressive model. Meanwhile, ADF test is the same as the Dicky-Fuller test, except that it is augmented by including $\mathrm{m}$ lags of independent variable $\left(\Delta Y_{t}\right)$ to correct any serial correlation in the disturbance term. The null hypothesis remained as above. The ADF Test consist of three models which are:

Test for unit root:

$$
\Delta Y_{t}=\delta Y_{t-1}+\sum_{i=1}^{m} \gamma_{i} \Delta Y_{t-1}+\mu_{t}
$$

Test for unit root with drift

$$
\Delta Y_{t}=\alpha+\delta Y_{t-1}+\sum_{i=1}^{m} \gamma_{i} \Delta Y_{t-i}+\mu_{t}
$$

Test for unit root with drift and deterministic trend

$$
\Delta Y_{t}=\alpha+\beta t+\delta Y_{t-1}+\sum_{i=1}^{m} \gamma_{i} \Delta Y_{t-i}+\mu_{t}
$$

From the above model, the $\Delta Y_{t}$ is the first differential of the time series where $\Delta Y_{t}=Y_{t}-Y_{t-1}^{t} . m$ is the number of lags onto the dependent variable, while $\mu_{t}$ is the white noise error term in the model. Schwert (1989) suggest that the rule of thumb to determine the maximum number of lagged term $(\mathrm{m})$ in the $\mathrm{ADF}$ test equations. 
Foo Tzen YOONG, Abdul Rahman Abdul LATIP, Nur Azura SANUSI, Suhal KUSAIRI /

$$
m=\text { interger part of }\left[12 \cdot\left(\frac{T}{100}\right)^{\frac{1}{4}}\right]
$$

Where $\mathrm{T}=$ total time points for which data are available.

If the calculated $\tau_{\delta}^{*}$ lies to the right of critical $\tau$ at our chosen level of significance, we accept the null hypothesis and conclude that the series has unit root, and hence non-stationary. Before analyzing using the above three ADF models, a graph should be plotted and observe the presence or absence of drift (intercept), deterministic trend, and unit root in the series.

\subsubsection{Philips-Perron Test}

Assumption of ADF test is based on the seriallyindependent error term and has variance of constant. While, PP make a correction to the computed $\tau$ - statistic of the estimated coefficient to account for correlation in the error term $\mu_{t}$. Thus, PP Test is a less restrictive on the error process of ADF test. It has shown that the distribution of PP test $\tau$-statistic distribution is the same as the distribution in ADF test $\tau-$ statistic. The ADF critical value still applies here.

$$
\Delta Y_{t}=\delta Y_{t-1}+u_{t}
$$

\subsubsection{Autoregressive Distributed Lag (ARDL)}

This model is applied for the examination of the relationship between variables and run stationarity test. The cointegration offers a remedy to the problem of differencing method. When the series is non-stationary, but once it is differenced once, the differenced series become stationary. Now, the series is said to be integrated to order of 1 or I(1). If the series is differenced twice and become stationary, it will be $\mathrm{I}(2)$. In general, if the series is differenced for $\mathrm{d}$ times to make it stationary, then it is integrated as I(d).

The advantage of using ARDL model is that this model incorporate $\mathrm{I}(0)$ and $\mathrm{I}(1)$ variables in the same equation. Then OLS is applied to analyze the equation. The OLS estimates will be efficient and consistent. To estimate using the ARDL, variables can only be I(0) or I(1), there shouldn't be any variable that is $I(2)$. First, we need to check on the stationarity of all variables before conducting ARDL.

$$
\begin{aligned}
\Delta L G D P P C_{t}= & \sum_{i=1}^{n} \beta_{1} \Delta L G D P P C_{t-i}+\sum_{i=0}^{n} \beta_{2} \Delta L D E B T_{t-i} \\
& +\sum_{i=0}^{n} \beta_{3} \Delta L G E X P_{t-i}+\sum_{i=0}^{n} \beta_{4} \Delta L H E X P_{t-i} \\
& +\alpha_{1} L G D P P C_{t-1}+\alpha_{2} L D E B T_{t-1} \\
& +\alpha_{3} L G E X P_{t-1}+\alpha_{4} L H E X P_{t-1}+\mu_{t}
\end{aligned}
$$

Where:

LGDPPC = Logarithm of Gross Domestic Product Per Capita Growth

LDEBT $=$ Logarithm of Debt-to-GDP ratio

LGEXP = Logarithm of Government Expenditure to GDP ratio

LHEXP = Logarithm of Household Expenditure to GDP ratio

Once the variables are observed as integrated of stationary, order one I(1) or order zero I(0), the Bounds test or ARDL could be carried out. This test will look for the existence of level relationships between the variables regardless of integrated of order one or zero. The ARDL model above are developed to study the long-run and short-run relationships between the economic growth and other variables.

Based on the above equations, the term summation signs refer to the error correction dynamics while the alpha appear for the long-run relationship. The null hypothesis for the above equation is $H_{0}: \alpha_{1}=\alpha_{2}=\alpha_{3}=\alpha_{4}=0$. It indicates the non-existence of the long-run relationship, while the alternate hypothesis is $H_{1}: \alpha_{1} \neq \alpha_{2} \neq \alpha_{3} \neq \alpha_{4} \neq 0$. When the computed F-statistics falls below the lower bound critical value at prescribed level of significance, the null hypothesis is not rejected.

Therefore, this study could conclude that there is no long-run relationship. If the computed F-statistics fall in between the upper and lower critical bound, the decision will be inconclusive. When the F-statistics exceed the upper bound of the critical value, then the null hypothesis of no cointegration is rejected. If these hypothesis tests identify the existence of co-integration between variables, then we could proceed to the second step of ARDL.

The second step of ARDL is to determine the optimal lag length for the model. The optimal lag length for the model will be selected using the model selection criteria like Schwartz-Bayesian Criterion (SBC) or Akaike Information Criterion (AIC). Selecting the appropriate number of lags for the model is not specified by any economic theory, however the criteria above are often used to select the lag length optimally. This step in determining the lag length is crucial in ARDL because the appropriate lag length will enable us to identify the true dynamics of the model.

The robustness of the ARDL bound test of co-integration can be confirmed by using the Johansen and Juselius (1990) maximum livelihood estimation. The test will be carried out under Vector Auto Regressive (VAR).

\section{Results and Discussion}

This paper used the yearly data from Bank Negara Malaysia and World Development Indicators to test the timeseries relationships using ARDL framework. The first step 
of the cointegration method is to test for the presence of unit root among the variables.

\subsection{Stationarity Test}

To test for the presence of unit root in these variables, the $\mathrm{ADF}$ test is deployed for each and every variable. The results show that all the variables are integrated to level or the first difference, which is $\mathrm{I}(0)$ or $\mathrm{I}(1)$. We could see that the LGDPPC is stationery at level with intercept, while all the other variables, LDEBT, LGEXP and LHEXP are stationery at first difference without trend and intercept.

The results from Phillips-Perron test show that LGDPPC is stationery at level, while LDEBT, LGEXP and LHEXP are stationery at first difference. All are significant at 1\%. Both Phillips-Perron test and Augmented Dicky-Fuller test show that these variables are either integrated at level or integrated at first difference, $\mathrm{I}(0)$ or I(1). Therefore, the Autoregressive Distributed Lag could be performed as there is no data that are $\mathrm{I}(2)$ or all are $\mathrm{I}(0)$ or $\mathrm{I}(1)$.

\subsection{Cointegration Tests}

Next, the cointegrating tests will be performed and F-statistics will be computed. The critical bounds are obtained from Narayan (2004) with I(0) as the lower bound and the I(1) as the upper bound. If the computed F-statistics fall below the lower bound, we will conclude that there is no co-integrating relationship between the variables. If the computed F-statistics fall between the lower bound and upper bound, we will conclude that it is inconclusive. When the computed F-statistics exceed the upper bound, the null hypothesis of no co-integrating could not be accepted, therefore we could conclude that there is a co-integrating relationship between the variables.

In Table 1, Bound tests for cointegration, the critical value for $5 \%$ and $10 \%$ significant are obtained from Narayan (2004) with number of regressors of 3 and sample size of 46. The computed F-statistics is 36.70701 and it is higher than the upper bound for both 5\% and 10\% significant level. Thus, it is concluded that the variables are co-integrated.

The LGDPPC(-1) is significant at $1 \%$ level and it has a negative sign. A $1 \%$ increase in the lagged GDP per capita will result in a $1.17 \%$ decrease in the GDP per capita. A $1 \%$ increase in the lagged Debt ratio results in a $0.42 \%$ decrease in the GDP per capita and it is significant at $10 \%$. A $1 \%$ increase in government expenditure will result in $1.79 \%$ increase in the GDP per capita. A $1 \%$ increase in the household expenditure will result in a $0.0059 \%$ increase in GDP per capita, however, the coefficient is not significant. This suggests that higher government expenditure will result in an increase in the GDP per capita in the long run, while, higher debt ratio will result in a lower GDP per capita in the long run (see Table 2).

Table 1: Bound Tests for cointegration

\begin{tabular}{|l|l|c|c|c|c|}
\hline \multicolumn{2}{|c|}{ Case III: Unrestricted Intercept and no trend } \\
\cline { 1 - 5 } & & \multicolumn{3}{|c|}{ Critical value bounds of F statistics } \\
\cline { 3 - 6 } & & \multicolumn{2}{|c|}{$\mathbf{5 \%}$ level } & \multicolumn{2}{c|}{$\mathbf{1 0 \%}$ level } \\
\hline Dependent Variable & Calculated F-statistic & $\mathrm{I}(0)$ & $\mathrm{I}(1)$ & $\mathrm{I}(0)$ & $\mathrm{I}(1)$ \\
\hline $\mathrm{D}$ (LGDPPC) & 36.70701 & 3.535 & 4.733 & & 3.983 \\
\hline & $\mathrm{k}=3 \mathrm{n}=46$ & & & & \\
\hline
\end{tabular}

Note: The critical value bounds are from Table for Critical values for the bounds test: case III: unrestricted intercept and no trend in Narayan (2004). $\mathrm{k}$ is the number of regressors.

Table 2: Long Run Coefficients Estimate

\begin{tabular}{|l|c|c|}
\hline $\begin{array}{l}\text { Variables } \\
\text { (Dependent variable is DLGDPPC) }\end{array}$ & Coefficients & t-Statistics \\
\hline Constant & -1.4042 & -0.4404 \\
\hline LGDPPC(-1) & $-1.1738^{* * *}$ & -11.4029 \\
\hline LDEBT(-1) & $-0.4284^{*}$ & -1.9158 \\
\hline LGEXP & $1.7946^{* * *}$ & 2.7223 \\
\hline LHEXP & 0.0059 & 0.0048 \\
\hline D(LDEBT) & $-5.3763^{* * *}$ & -8.8171 \\
\hline
\end{tabular}

Note: ${ }^{* *},{ }^{* *}$ and ${ }^{*}$ mean significant at $1 \%, 5 \%$ and $10 \%$. 
The error correction coefficient for this model is -1.1738 , which suggests that, once shocked, convergence to equilibrium is around $117 \%$ (see Table 3 ). This means that about $117 \%$ of any movements into disequilibrium is corrected within one year. The error correction term is high significant at $1 \%$. When the ECM is non-zero (positive or negative), there is a disequilibrium in the short run. However, equilibrium will be restored in the long run if and only if the coefficient is less than 0 . As the coefficient is negative, so it will be negative to restore equilibrium. (Sankar, 2015)

If the error correction term is between -1 and -2 , then the lagged error correction term produces dampened fluctuations. The error correction term of -1.17 implies that there is a converging to the equilibrium directly, but it fluctuates around the long-run value in a dampening manner. However, once the process is complete, the convergence is rapid. (Narayan, 2006). The model went through the diagnostic tests and the Breush-Godfrey Serial Correlation LM test is to test whether the error terms are autocorrelated. The null hypothesis is no autocorrelation, while the alternate hypothesis has autocorrelation.

Table 4 shows the Breusch-Godfrey Serial Correlation LM test, the computed F-statistics in 0.0203 and the probability is 0.9799 . We can conclude that we failed to reject the null hypothesis. Thus, the error terms are not autocorrelated. The model was tested to check the existence of heteroskedasticity. The null hypothesis is that errors are homoscedastic, while the alternate hypothesis is heteroskedastic. The result from heteroskedasticity using the ARCH test is indicated in Table 4, the computed F-statistics is 1.6823 and the probability is 0.2015 , so we could conclude that this study cannot reject the null hypothesis. Therefore, the errors in the model are homoskedastic and independent of the regressors. As regards the Ramsay RESET tests for model mis-specification, the null hypothesis of the study has the coefficients zero and the coefficients of the alternate hypothesis are non-zero. The computed F-statistics is 1.5905 and the probability is 0.1198 , thus we could conclude that we cannot reject the null hypothesis. This means our model did not suffer from mis-specification.

In evaluating the stability of the regression coefficients, the cumulative sum of squares (CUSUMSQ) of the recursive residual test and the cumulative sum (CUSUM) were used. The lines in red are the $5 \%$ significance level for both tests. Lastly, we could conclude that the regression equation seems to be stable as neither of the CUSUMSQ or CUSUM test statistics surpass the bounds of the 5\% level of significance (see Figure 2).

Table 3: Error Correction Regression

\begin{tabular}{|l|c|c|}
\hline $\begin{array}{l}\text { Variables } \\
\text { (Dependent variable is DLGDPPC) }\end{array}$ & Coefficients & Standard Error \\
\hline C & -1.4042 & $0.1226^{* * *}$ \\
\hline D(LDBT) & -5.3763 & $0.5228^{* * *}$ \\
\hline CointEq(-1) & -1.1738 & $0.0934^{* * *}$ \\
\hline
\end{tabular}

Note: ${ }^{* * *}$ mean significant at $1 \%$.

Table 4: Breusch-Godfrey Serial Correlation LM Test, Heteroskedasticity Test: ARCH, Ramsay RESET Test

\begin{tabular}{|c|c|}
\hline \multicolumn{2}{|c|}{ Breusch-Godfrey Serial Correlation LM Test } \\
\hline F-statistics & 0.0203 \\
\hline Prob. F & 0.9799 \\
\hline Obs*R-squared & 0.0491 \\
\hline Prob. Chi-Square & 0.9757 \\
\hline \multicolumn{2}{|c|}{ Heteroskedasticity Test: ARCH } \\
\hline F-statistics & 1.6823 \\
\hline Prob. F & 0.2015 \\
\hline Obs*R-squared & 1.6943 \\
\hline Prob. Chi-Square & 0.1930 \\
\hline \multicolumn{2}{|c|}{ Ramsay RESET Test } \\
\hline t-statistics & 1.5905 \\
\hline Prob. & 0.1198 \\
\hline F-statistics & 2.5297 \\
\hline Prob. & 0.1198 \\
\hline
\end{tabular}



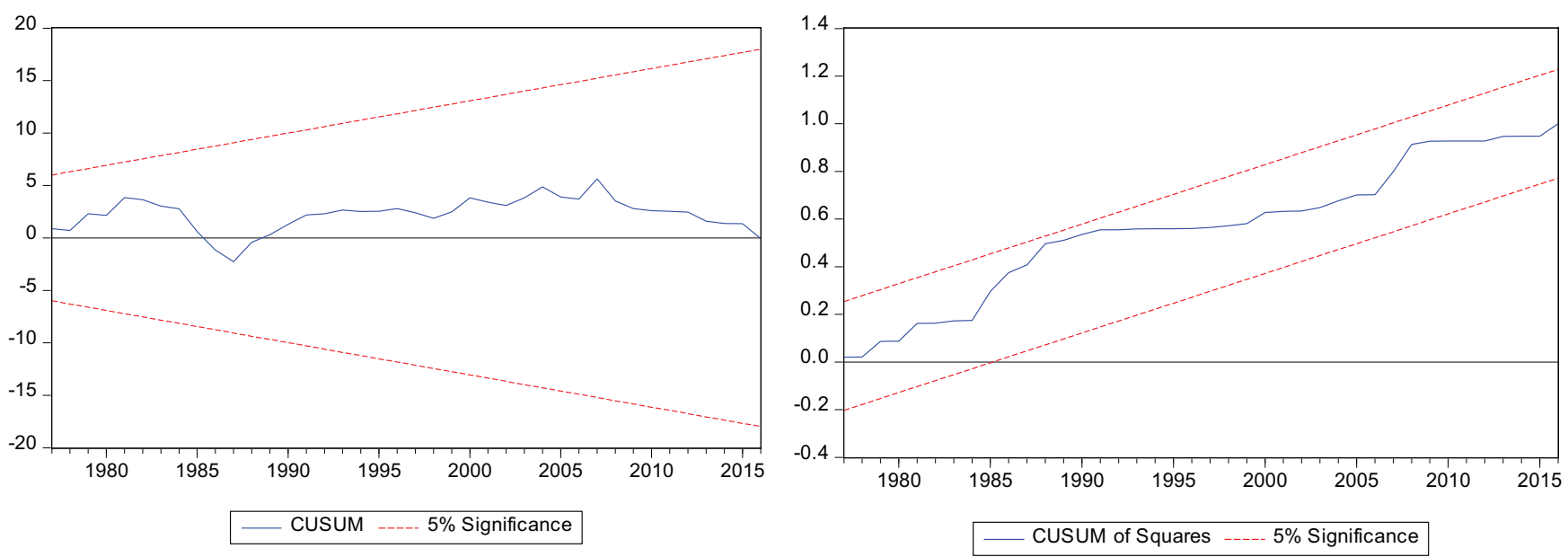

Figure 2: CUSUM and CUSUMSQ test statistics

\section{Conclusions}

In this study, we used the approach formulated by Pesaran et al. (2001), which called for the bounds testing approach to cointegration by examining the relationship of time-series between debt ratio and economic growth. We used the ARDL approach to estimate the determinants. We have included the government expenditure and household expenditure as the determinants of GDP growth per capita. The results indicated that there is a long-run equilibrium relationship between GDP per capita and the other determinants.

The error correction term is -1.1738 , which indicates the speed of adjustment towards the equilibrium followed by a shock to the system. The coefficient value has the correct sign $(-1.1738)$, however, the coefficient is between -1 and -2 and is significant at $1 \%$ level. In the short run of the model, there could be disequilibrium, but in the long run, the equilibrium could be restored (Sankar, 2005). The value of coefficient higher than -1 also implies that there is a converging to the equilibrium directly with fluctuations around the long-run value in a dampening manner. The convergence is rapid once the process is completed. (Narayan, 2006).

We summarize our key findings as below:

a. In the long run, a $1 \%$ increase in the lagged GDP per capita reduces the GDP per capita by $1.17 \%$

b. In the long run, a $1 \%$ increase in government expenditure increases the GDP per capita by $1.79 \%$ and a $1 \%$ increase in the difference of debt ratio reduces the GDP per capita by $5.37 \%$.

c. We found that the household expenditure positively impact the GDP per capita, however it is not significant.

We see that in the long run, government expenditure has the most influence on the GDP per capita. However, when government expenditure needs to be financed by taxpayers through taxes or through government borrowings, debt is created. The difference of debt ratio will decrease the GDP per capita by $5.37 \%$, which is higher than the influence of government expenditure in the long run. Our results align with previous research on the impact of public debt on economic growth in the long run done by Combes et al (2017), Schularick (2012), Égert (2015), and Carmen et. al (2016).

Through our result, we found that the government expenditure could indeed increase the GDP per capita, which is contrary to the Ricardian view. Ricardians view that the crowding effect will force out the investment. In other words, the government expenditure will have no effect on the output of a nation. Our result fit more with the Keynesian theory where expectation by the public could increase the output when the government expenditure increases.

We should see the policy towards higher government expenditure for a higher GDP per capita, but a policy towards lower debt ratio for a higher GDP per capita. This will be a tough decision for the Malaysian Government as the budget has been in deficit since 1998. If the government expenditure is going to be raised for a higher GDP per capita, the budget deficit will worsen. The Government has been setting targets on fiscal deficit target of 2.8\%-3\% of GDP. Fiscal deficit is when government expenditure exceed government revenue, excludes borrowing.

An increase of the debt ratio in the result could decrease the GDP per capita. In promoting economic growth, it is essential to have policies that could reduce the size of federal debt. Policies such as restructuring federal debt could be pursue to obtain a lower debt ratio.

Malaysia should achieve a level of government expenditure that is optimum and a debt ratio that is sufficient to finance the government services, and at the same time promote economic growth. 
Foo Tzen YOONG, Abdul Rahman Abdul LATIP, Nur Azura SANUSI, Suhal KUSAIRI /

Journal of Asian Finance, Economics and Business Vol 7 No 11 (2020) 137-145

\section{References}

Al-Zeaud, H. A. (2014). Public Debt and Economic Growth: An Empirical Assessment. European Scientific Journal, 10(4). doi: 10.19044/esj.2014.v10n4p\%p

Aleksandar, T., Dragan I., \& Anastazija T., D. (2014). Consequences of Fiscal Deficit and Public Debt in Financing the Public Sector. Economics of Agriculture, 61(1), 1-18.

Alfredo, M., Pereira, \& Pedro, G. R. (2001). Public Debt and Economic Performance. Working Paper No. 20. Retrieved from https://10envolver.files.wordpress.com/2012/05/dgep-wp20pd-and-ec-perf-2001.pdf

Blake, T. (2015). Investigating the Impact of Public Debt on Economic Growth in Jamaica. Working Paper. Retrieved from https://pdfs.semanticscholar.org/7be7/3b4893062a3186e 38ebf1d67babc6768ca72.pdf? ga=2.262920780.1335047429. 1599143173-1252148163.1570095853

Carmen, M., Ramos-Herrera, \& Simon, S. (2015). An Empirical Characterization of The Effects of Public Debt on Economic Growth. Applied Economics, 49(35), 3495-3508.

Combes, J., Minea, A., \& Sow, M. (2016). Is Fiscal Policy Always Counter- (Pro-) Cyclical? The Role of Public Debt and Fiscal Rules. Economic Modelling, 65, 138-146.

Da Veiga, J., Ferreira-Lopes, A., Neves Sequeira, T., \& Serra Santos, M. (2019). Explaining Growth in African Countries - What Matters? Acta Oeconomica, 69(3), 467-484. doi: 10.1556/032.2019.69.3.7

Égert, B. (2015). The 90\% Public Debt Threshold: The Rise and Fall of a Stylized Fact. Applied Economics, 47, 34-35.

Fekadu, M. (2014). The Impact of External Debt on Economic Growth in Ethiopia. Unpublished Doctoral thesis, Addis Abba University, Ethiopia

Kumar, K., \& Paramanik, R. (2020). Nexus between Indian Economic Growth and Financial Development: A Non-Linear ARDL Approach. Journal of Asian Finance, Economics and Business, 7(6), 109-116. doi: 10.13106/jafeb.2020.vol7. no6.109
Lee, S., \& Ng, Y. (2015). Public Debt and Economic Growth in Malaysia. Asian Economic and Financial Review, 5, 119-126.

Matiti, C. (2013). The Relationship between Public debt and Economic Growth in Kenya. International Journal of Social Sciences and Project Planning Management, 1(1), 65-86.

Mencinger, J., Aleksander, A., \& Miroslav, V. (2014). The Impact of Growing Public Debt on Economic Growth in the European Union. Amfiteatru Economic, 16(35), 403-414.

Olilingo, F., \& Putra, A. (2020). How Indonesia Economics Works: Correlation Analysis of Macroeconomics in 2010 - 2019. Journal of Asian Finance, Economics and Business, 7(8), 117130. doi: 10.13106/jafeb.2020.vol7.no8.117

Pesaran, M., Shin, Y., \& Smith, R. (2001). Bounds testing approaches to the analysis of level relationships. Journal of Applied Econometrics, 16(3), 289-326. doi: 10.1002/jae.616

Reinhart, C., \& Rogoff, K. (2010). Growth in a Time of Debt. American Economic Review, 100(2), 573-578.

Schularick, M. (2012). Public Debt and Financial Crises in the Twentieth Century, European Review of History, 19(6), 881-897.

Soludo, C. C. (2003). The Debt Trap in Nigeria: Towards a Sustainable Debt Strategy. Trenton, NJ: Africa World Press.

Tan, Y. F., \& Chin, M. Y. (2017). Revisiting the Role of Public Debt in Economic Growth: The Case of Malaysia. Advanced Science Letters, 23(4), 3163-3166.

Tariq, R., Khan, M., \& Rahman, A. (2020). How Does Financial Development Impact Economic Growth in Pakistan?: New Evidence from Threshold Model. Journal of Asian Finance, Economics and Business, 7(8), 161-173. doi: 10.13106/ jafeb.2020.vol7.no8.161

Zouhaier, H., \& Fatma, M. (2014). Debt and Economic Growth. International Journal of Economics and Financial Issues, 4(2), 440-448.

Zakaria, Z., \& Nabi, M. H. (2015). The Causality Relationship Between Public Debt, Economic Growth and Export in Malaysia. Advanced Science Letters, 21(6), 1725-1728. 